\title{
Активність та участь дітей із церебральним паралічем в аспекті ерготерапії та фізичної терапії
}

\author{
удк 796:616.831-009.11-053.4-085 \\ О. О. Кущенко
}

Національний університет фізичного виховання і спорту України, Київ, Україна

\begin{abstract}
Резюме. Рівень та процес формування побутових і соціальних навичок у дітей із церебральним паралічем, а також вплив на нього ерготерапії та фізичної терапії, є актуальним об'єктом вивчення. Мета. Оцінити рівень розвитку великих моторних функцій та функції рук, дослідити рівень можливостей у самообслуговуванні, мобільності та соціальній функціональності у дітей з церебральним паралічем. Методи: 106 пацієнтів (54 зі спастичною геміплегією - ГП та 52 зі спастичною диплегією - ДП) віком 4-6 років було обстежено відповідно до GMFCS, MACS та PEDI. Результати. Серед дітей із церебральним паралічем у групі з ГП за GMFCS II рівень становив 25,9 \% дітей, III - 53,7 \%, IV - 20,4 \%; у групі з ДП - відповідно 11,6 \%, 36,5 \% та 51,9 \% дітей. Серед групи з ГП за MACS II рівень мали 11,1 \% дітей, III - 55,6 \%, IV - 33,3 \%; у групі з ДП - відповідно $25 \%$, 63,5 \% та 11,5 \% дітей. Середнє значення загальної суми розділу самообслуговування за PEDI дорівнювало 29,7 \pm 8,09 бала у групі дітей з ГП та 33,5 \pm 7,58 бала у групі з ДП із можливих 73 балів. Отримані значення загальної суми розділу мобільності становили 27,3 \pm 9,72 бала у групі з ГП та 22,2 \pm 8,05 бала у групі з ДП при можливих 59 балах. Статистичні показники загальної суми розділу соціальної функціональності за PEDI були $36,5 \pm$ $\pm 4,94$ бала у групі дітей з ГП та 38,0 5, 33 бала у групі з ДП з можливих 65. Висновки. Групи дітей мали значно знижені показники рівня активності та участі, що свідчить про необхідність вжиття заходів щодо їх поліпшення, зокрема ерготерапії та фізичної терапії.

Ключові слова: самообслуговування, побутові та соціальні навички, фізичні вправи, терапія.
\end{abstract}

\section{Активность и участие детей с церебральным параличом в аспекте эрготерапии и физической терапии \\ А. А. Кущенко}

Резюме. Уровень и процесс формирования бытовых и социальных навыков у детей с церебральным параличом, а также влияние на него эрготерапии и физической терапии, является актуальным объектом изучения. Цель. Оценить уровень развития моторных функций и функции рук, исследовать уровень возможностей в самообслуживании, мобильности и социальной функциональности у детей с церебральным параличом. Методы: 106 пациентов (54 со спастической гемиплегией - ГП и 52 со спастической диплегией - ДП) в возрасте 4-6 лет были обследованы в соответствии с GMFCS, MACS и PEDI. Результаты. Среди детей с церебральным параличом в группе с ГП по GMFCS II уровень составлял 25,9 \% детей, III 53,7 \%, IV - 20,4 \%; в группе с ДП - соответственно 11,6 \%, 36,5 \% и 51,9 \% детей. Среди группы с ГП по MACS II уровень имели 11,1\% детей, III - 55,6 \%, a IV - 33,3 \%; в группе с ДП соответственно 25 \%, 63,5 \% и 11,5 \% детей. Среднее значение общей суммы раздела самообслуживания по PEDI было равно 29,7 \pm 8,09 балла в группе детей с ГП и 33,5 \pm 7,58 балла в группе с ДП из возможных 73 баллов. Полученные значения общей суммы раздела мобильности составили 27,3 \pm 9,72 балла в группе с ГП и 22,2 1 8,05 балла в группе с ДП из возможных 59 баллов. Статистические показатели общей суммы раздела социальной

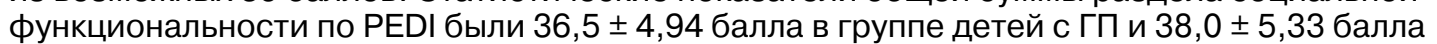
в группе с ДП из возможных 65. Выводы. Группы детей имели значительно сниженые показатели уровня активности и участия, что свидетельствует о необходимости принятия мер по их улучшению, в частности эрготерапии и физической терапии.

Ключевые слова: самообслуживание, бытовые и социальные навыки, физические упражнения, терапия.

The activity and participation of children with cerebral palsy in the aspect of ergotherapy and physical therapy

O. O. Kushchenko

Abstract. The level and process of forming household and social skills in children with cerebral palsy, as well as the influence of ergotherapy and physical therapy on it, is an actual subject of study. Objec- 
tive. To evaluate the level of development of large motor functions and functions of hands, to examine the level of possibilities for self-service, mobility and social functionality in children with cerebral palsy. Methods: 106 patients (54 with spastic hemiplegia - GP and 52 with spastic diplegia - DP) aged 4-6 years were examined according to GMFCS, MASS and PEDI. Results. Among children with cerebral palsy in the group with GP for GMFCS II level is $25.9 \%$ of children, III - 53.7\%, IV - $20.4 \%$; in the group with DP - $11.6 \%, 36.5 \%$ and $51.9 \%$ of children, respectively. Among the group with the GP for MASS II level had $11.1 \%$ of children, III $55.6 \%$, and IV - 33.3 \%; in the group with DP - $25 \%, 63.5 \%$ and $11.5 \%$ of children, respectively. The average value of the total self-service section for PEDI was $29.7 \pm 8.09$ points in the group of children with GP and $33.5 \pm 7.58$ points in the group with the GP of the possible 73 points. The obtained values of the total amount of the mobility section were $27.3 \pm 9.72$ points in the group with the GP and $22.2 \pm 8.05$ points in the group with the GP of possible 59 points. The statistical indices of the total amount of the section of social functionality for PEDI were $36.5 \pm 4.94$ points in the group of children with GP and $38.0 \pm 5.33$ points in the group with the DP of the possible 65. Conclusions. The children's groups had significantly decreased levels of activity and participation, indicating the need to take measures to improve them, including ergotherapy and physical therapy. Keywords: self-service, domestic and social skills, physical exercises, therapy

Постановка проблеми. Аналіз останніх досліджень і публікацій. Дитячий церебральний параліч (ДЦП) $є$ найчастішою причиною рухових порушень у дитячому віці $[16,18,22]$. Залежно від підгрупи ДЦП 25-80\% пацієнтів крім рухових мають додаткові порушення. Велика частка дітей має когнітивні порушення, хронічний біль, порушення мови [18]. Церебральний параліч $\epsilon$ гетерогенною групою синдромів, які виникають внаслідок пошкодження мозку у внутрішньоутробному, інтранатальному й ранньому постнатальному періодах, що призводить до сенсорних, перцептивних, когнітивних та поведінкових розладів, а також вторинних скелетно-м'язових проблем [20].

Важливим індикатором здоров'я та передумовою до застосування засобів фрізичної реабілітації $€$ фрізичний розвиток дітей $[4,6,25]$. У дітей із церебральним паралічем у повному обсязі не працює рухова фрункціональна система, яка $\epsilon$ надзвичайно важливою для нормального рівня активності та участі людини. Серед клінічних проявів церебральних паралічів виділяють підвищення та зниження м'язового тонусу, гіперкінези, порушення рівноваги, координації [2].

Проте деякі діти з ДЦП розвиваються майже так само, як і звичайні діти, за винятком відхилень в освоєнні рухових навичок $[1,14]$.

Така неоднорідність резидуальних наслідків після травми головного мозку свідчить про необхідність комплексного застосування медичних, реабілітаційних, освітніх та соціальних ресурсів для фрізичного і психологічного відновлення хворої дитини $[10,15,19]$. Обмеження у діяльності обумовлюють потребу в індивідуальній реабілітації протягом усього життя [15, 21, 23]. Низька працездатність верхніх кінцівок, знижені опорна функція нижніх кінцівок та статокінетичні можливості хребта обмежують побутові можливості самообслуговування і соціальне функціонування дітей з ДЦП [3]. Крім того, залучення батьків до реабілітації $€$ важливим, як і в інших групах дітей [5].

У літературі не наведено конкретні методи лікування, які можуть відновити пошкодження головного мозку, відповідального за складні клініко-фрункціональні порушення, характерні для ДЦП. Однак існує багато заходів, що спрямовані на зменшення вторинних проявів щодо пошкодження мозку і підвищення рівня активності та участі цих пацієнтів, i, отже, якості їх життя. Велика варіабельність клінічних аспектів, складність та комплексність порушених фрункцій визначають розвиток різноманітних компенсаторних навичок у дітей з ДЦП. Існує також значна необхідність у забезпеченні їх довгострокового догляду, з урахуванням медичних і соціальних аспектів, а також реабілітації, освіти та допомоги [24].

Одними 3 важливих напрямків комплексного лікування $\epsilon$ ерготерапія, яка фокусується на розвитку необхідних для здійснення діяльності в повсякденному житті навичок, та фрізична терапія, котра спрямована на нормалізацію моторних фрункцій.

У сучасних умовах процес формування основ та самих побутових і соціальних навичок засобами ерготерапії та фрізичної терапії у дітей із ДЦП вимагає освоєння закордонного досвіду [11], створення новітніх орієнтирів соціальної реабілітації та застосування міждисциплінарного підходу [9, 12, 24], врахування поліморфності клінічних проявів та складності патогенезу церебральних паралічів [15], а також творчого підходу у фохівців [9].

Тому доцільним $\epsilon$ вивчення рівня функціонування, активності, участі, формування соціальнопобутових навичок для побудови загальних та 
індивідуальних програм ерготерапії та фрізичної терапії для дітей з ДЦП.

Зв'язок роботи з науковими темами. Роботу виконано згідно з «Планом НДР НУФВСУ на 2016-2020 рр.» за темою 4.2. «Організаційні та теоретико-методичні основи фрізичної реабілітації осіб різних нозологічних, професійних та вікових груп» (номер держреєстрації 0116U001609).

Мета дослідження - оцінити у дітей $з$ церебральним паралічем рівень великих моторних фрункцій та фрункції рук, дослідити рівень можливостей у самообслуговуванні, мобільності та соціальній орункціональності.

Методи дослідження. У дослідженні взяли участь 106 пацієнтів, що проходили курс ерготерапії та фрізичної терапії у «Київському міському центрі реабілітації дітей з інвалідністю» та у спеціальному навчально-виховному комплексі «Мрія» (м. Київ) з діагнозом дитячий церебральний параліч за 2017 р. Частка зі спастичною геміплегією (ГП) становила 54 особи (50,9\%), а зі спастичною диплегією (ДП) - 52 (49,1%).

Для вирішення мети було використано Gross Motor Function Classification System (GMFCS) [17], Manual Ability Classification System (MACS) [7], Педіатричну оцінку обмежень активності (Pediatric Evaluation of Disability Inventory (PEDI)) [8]. Відзначимо, що максимально можливий бал у розділах PEDI становить: самообслуговування - 73 бали; мобільність - 59 балів; соціальна функціональність - 65 балів.

Матеріали дослідження опрацьовано в програмі статистичного аналізу IBM SPSS 21. Математична обробка числових даних проводилася за допомогою методів варіаційної статистики. Аналіз за критерієм Шапіро-Уілкі (W) не виявив відповідності розподілу кількісних показників закону нормального розподілу. Тож для кількісних показників визначали медіану (Ме) та верхній і нижній квартилі (25\%; 75 \%), а також додатково середнє значення $(\bar{x})$ та середньоквадратичне відхилення (S). Для оцінки значущості різниці використовували U-критерій Манна-Уітні.

Результати дослідження. У групі з ГП за класифікацією GMFCS II рівень мали 14 дітей $(25,9 \%)$, III - 29 (53,7 \%), IV - 11 дітей $(20,4 \%)$, а у групі з ДП відповідно 6 (11,6\%), $19(36,5 \%)$ та 27 (51,9 \%) дітей. Серед групи ГП за класифрікацією MACS II рівень мали 6 дітей $(11,1 \%)$, III - 30 (55,6 \%), a IV - 18 (33,3\%) дітей, а у групі ДП II рівень мали 13 (25\%) дітей, III рівень - 33 (63,5 \%), a IV - 6 (11,5 \%) дітей.

Відповідно до результатів оцінки показників розділу самообслуговування, яка більшою мірою відображає поняття «активність повсякденного життя» (Activities of Daily Living) та необхідні виконавчі уміння та навички, було встановлено достовірні відмінності між групами дітей ГП та ДП. Цей фракт співвідноситься $з$ наявністю достовірних відмінностей у розподілі рівнів за GMFCS та MACS ( $p<0,01)$.

Розділ самообслуговування включає в себе 15 пунктів. Перший із них «консистенція їжі, яку споживає». Так, показники Ме (25 \%; 75 \%) зафріксовано у групі ГП на рівні $2(2 ; 3)$ бали при середньому 2,3 \pm 0,76 бала, а серед дітей з ДП - 3 (2; 3) бали при середньому 2,8 \pm 0,86 бала (p $<0,01)$. Результати пункту «використання посуду для їжі», що варіює залежно від здатності їсти пальцями до використання ножа, було встановлено на рівні $2(1 ; 2)$ бали при середньому $1,7 \pm 0,73$ бала у дітей з ГП та 2 (1,3; 3) бали у дітей з ДП ( $<<0,05)$ при середньому значенні 2,1 \pm 0,85 бала. Отримані бали за пункт «використання ємностей для пиття» зафріксовано на рівнях $2(2 ; 3)$ та $3(2 ; 3)$ у дітей груп ГП та ДП відповідно ( $<0,01)$. А середні значення становили 2,3 \pm 1,03 та 2,9 \pm 0,76 бала.

Отримані показники при оцінці виконання пункту «чищення зубів» було встановлено на рівні 2 (2; 2) бали серед дітей групи ГП та 2 $(2 ; 3)$ бали серед дітей групи ДП. Середні значення відповідно 2,0 \pm 0,63 та 2,2 \pm 0,59 бала. Оцінка навички розчісувати волосся та одноіменного пункту шкали виявили статистичні показники $\mathrm{Me}(25 \% ; 75 \%)$ у групі ГП на рівні $2(1 ; 2)$ бали при середньому значенні 1,8 \pm 0,70 бала, а серед дітей групи ДП - $2(1,3 ; 2,8)$ бали при середньому значенні 2,0 \pm 0,71 бала. За пункт «догляд за носом» групи ГП та ДП мали значення $\mathrm{Me}(25 \% ; 75 \%)$ на рівні $2(2 ; 3)$ та $3(2 ; 3)$ бали, а середні значення дорівнювали 2,4 \pm 0,92 та 2,7 \pm 0,86 бала відповідно. Відмінностей за цими пунктами не встановлено (р >0,05).

Пункт «гігієна рук» мав показники на рівні $2(1 ; 3)$ та $3(2 ; 3)$ бали у групах ГП та ДП відповідно ( $<0,01)$. Отримані бали за цей пункт вилилися у середні значення на рівні 2,0 $\pm 0,80$ та 2,5 \pm 0,80 бала для груп ГП та ДП відповідно.

Один із найнижчих балів мав пункт «миття тіла та обличчя»: ГП - $1(0 ; 1)$ бал; ДП $1(0,25 ; 1)$ бал ( $>>0,05)$. У групі дітей з ГП середнє значення становило 0,9 \pm 0,83 бала, а у групі ДП відзначено на рівні 1,1 \pm 0,91 бала. Оцінка Ме $(25 \% ; 75 \%)$ у пункті «одяг, що одягається через голову / застібається спереду» виявила значення на рівні $2(1 ; 2)$ та $2(1 ; 3)$ бали у ГП та ДП відповідно ( $<<0,05)$. Середні значення становили 1,7 \pm 0,66 та 2,0 \pm 0,79 бала. 
У пункті «застібки» значення Ме (25 \%; 75 \%) у групі ГП дорівнювало $1(1 ; 2)$ балу, а у групі ДП - $2(1 ; 2)$ бали. Середні значення відзначено на рівнях 1,5 $\pm 0,99$ та 1,7 $\pm 0,72$ бала відповідно. Оцінка навичок пункту «штани» виявила такі Ме (25 \%; 75 \%): ГП - 2 (1; 2) бали; ДП - 1,5 (1; 2) бала. Середні значення становили 1,6 $\pm 0,60$ та $1,4 \pm 0,87$ бала. Показники Ме (25\%; 75 \%) пункту «взуття/шкарпетки» були однаковими у групах - $1(0 ; 2)$ бал. Показники середніх значень у групах ГП та ДП становили 1,1 $\pm 1,03$ та $1,2 \pm 0,96$ бала відповідно. Значення Ме (25\%; 75 \%) пункту «завдання, пов'язані з туалетом» також були однаковими - $2(1 ; 3)$ бали, а середнє значення у групах ГП та ДП рівне 2,0 \pm 0,82 та 2,1 \pm 0,80 бала. Рівень контролю функцій сечового міхура оцінювався у $3(2 ; 3)$ бали серед дітей з ГП та $3(3 ; 4)$ бали у групі з ДП. Середні значення були на рівні 2,9 $\pm 0,71$ та 3,2 $\pm 0,61$ бала відповідно. Відмінностей за цими пунктами не встановлено ( $p>0,05)$.

Показники Ме (25\%; 75 \%) пункту «усвідомлення десрекації» були однаковими у групах -4 $(3 ; 4)$ бали $(p<0,05)$. Показники середніх значень у групах ГП та ДП становили 3,4 $\pm 0,73$ та $3,7 \pm 0,47$ бала відповідно.

Значення Мe (25\%; 75 \%) за загальним балом розділу самообслуговування склали 31,5 (21; 33) та $31,5(30 ; 39,8)$ бала у групах ГП та ДП $(\mathrm{p}<0,05)$.

Відповідно до результатів оцінки показників розділу мобільності, яка відображає поняття «руховові уміння та навички» (motor skills), було встановлено вірогідні відмінності у ряді пунктів між групами дітей з ГП та ДП. Цей фракт співвідноситься 3 наявністю вірогідних відмінностей у розподілі рівнів за GMFCS і MACS у групах дітей $(p<0,01)$.

Пункт «пересування до туалету» оцінений на рівні $2(1,75 ; 3)$ бали у групі ГП та $2(1 ; 2)$ бали у групі ДП ( $<0,01)$. При середніх значеннях 2,3 $\pm 0,99$ та 1,8 $\pm 0,85$ бала. Результати пункту «переміщення в крісло/інвалідний візок» склали $3(2 ; 4)$ та $2(2 ; 3)$ бали у групі ГП та ДП відповідно ( $<0,05)$, а середні значення становили 2,7 $\pm 1,09$ та 2,3 \pm 0,84 бала. Бали за пункт «переміщення в машині» зафріксовано на рівнях $2(1 ; 2)$ та $1(0 ; 2)$ у ГП та ДП відповідно $(p<0,05)$. Середні значення за цим пунктом становили 1,6 $\pm 1,07$ та 1,1 \pm 1,17 бала відповідно.

Отримані показники Me (25\%; 75 \%) у пункті «рухливість/переміщення в ліжку» було встановлено на рівнях $2(2 ; 3)$ та $2(2 ; 2)$ бали у групах ГП та ДП, при середніх 2,4 $\pm 0,56$ та 2,2 $\pm 0,51$ бала.
Оцінка навичок переміщення у ванні встановила такі бали у групах: ГП - 1 (1; 2); ДП - $1(1 ; 1)$. Середньостатистичні показники відповідно встановлено на рівнях $1,3 \pm 0,56$ та 1,2 $\pm 0,36$ бала. За пунктом «способи пересування в приміщенні» діти з геміплегією отримали $2(1,75 ; 3)$ бали при середньому - 2,0 \pm 0,71 бала, а з диплегією $2(1 ; 2)$ бали при середньому 1,8 \pm 0,62 бала. Відмінностей за цими пунктами не встановлено $(p>0,05)$.

Результати пункту «переміщення в межах дому - відстань/швидкість» було встановлено на рівні 3 (2; 4) бали при середньому 2,9 $\pm 1,36$ бала у дітей з ГП та $1(1 ; 3)$ бал у дітей з ДП (р < 0,01) при середньому значенні 2,0 \pm 1,40 бала. Отримані бали за пункт «переміщення в межах дому - перетягування / перенесення об'єктів» зафріксовано на рівнях $2(2 ; 3)$ та 2 (2; 2) бали у дітей груп ГП та ДП відповідно ( $<<0,05)$. Середні значення становили 2,3 \pm 0,44 та 2,0 \pm 0,44 бала. Пункт «переміщення надворі - способи» мав показники на рівні $1(0 ; 2)$ та $0(0 ; 1)$ балів у групах ГП та ДП ( $<<0,01)$. Середні значення отримано на рівні $1,0 \pm 0,74$ та 0,6 + 0,69 бала відповідно.

Пункт «переміщення за межами дому - відстань/швидкість» мав такі значення Me (25\%; 75 \%): ГП - 2 (2; 3) бали; ДП - 1 (1; 2) бал (р < 0,01). У групі дітей ГП середнє значення становило 2,2 \pm 0,96 бала, у групі з ДП $1,4 \pm 0,99$ бала.

Оцінка Ме (25\%; 75 \%) у пункті «пересування по типах поверхонь надворі» виявила однакові значення у групах $-2(1 ; 2)$ бали $(p<0,05)$. Середні значення становили $1,9 \pm 0,72$ та $1,9 \pm 0,70$ бала. У пункті «піднімання по сходах» значення Ме $(25 \% ; 75 \%)$ у групі ГП склало 2 $(2 ; 4)$ бали, а у групі ДП - $2(2 ; 2)$ бали (p < 0,01). Середні значення відзначено на рівнях $2,6 \pm 0,96$ та 2,2 \pm 0,69 бала відповідно. Оцінка навичок пункту «спускання по сходах» виявила такі значення Ме (25 \%; $75 \%)$ : ГП - $2(1 ; 3)$ бали; ДП - $2(1 ; 2)$ бали ( $>>0,05)$. Середні значення становили 2,2 $\pm 1,02$ та 1,9 $\pm 0,83$ бала.

Показники Ме (25 \%; 75 \%) загальної суми розділу мобільності у групах склали: ГП - 25 $(20,75 ; 40)$ та ДП - $20(16 ; 26)$ балів $(p<0,01)$.

Відповідно до результатів оцінки показників розділу соціальної функціональності, яка відображає зміст терміну «уміння та навички соціальної взаємодії» (social interaction skills), було встановлено вірогідні відмінності у значно меншій кількості пунктів між групами дітей ГП та ДП, порівняно з розділами самообслуговування та мобільності. 
Серед дітей, які мали геміплегічну фрорму, показники Ме (25 \%; 75 \%) пункту «розуміння значення слів» зафіксовано на рівні $4(4 ; 4)$ бали при середньому значенні 3,9 \pm 0,55 бала, а серед дітей з диплегічною формою - відповідно $4(4 ; 5)$ та 4,1 $\pm 0,66$ бала ( $>>0,05)$.

Результати пункту «розуміння складності речень» було встановлено на рівні $4(3 ; 4)$ бали у дітей з ГП та $4(3 ; 4)$ бали у дітей з ДП $(p<0,05)$. Середні значення відповідно склали $3,5 \pm 0,57$ та $3,9 \pm 0,64$ бала.

Пункт «фрункціональне користування спілкуванням» мав такі значення Ме (25\%; $75 \%)$ : ГП - 3 (3; 4) бали; ДП - 3,5 (3; 4) бала (р < 0,01). У групі дітей з ГП середнє значення становило $3,2 \pm 0,56$ бала, а у групі з ДП $-3,5 \pm 0,58$ бала.

У пункті «складність емоційного спілкування» значення Ме (25\%; $75 \%)$ у групі ГП склало 4 (3; 4) бали, а у групі ДП - $4(3,25 ; 4)$ бали. Середні значення відзначено на рівнях 3,8 0,67 та 3,9 \pm 0,77 бала відповідно. Оцінка навичок пункту «реакція дитини на власні проблеми» виявила наступні Ме (25\%; 75 \%): ГП 3 (3; 4) бали; ДП - 3 (3; 4) бали. Середні значення становили $3,2 \pm 0,87$ та 3,4 \pm 1,04 бала. Пункт «соціальні інтерактивні ігри з дорослими» оцінювався у $3(2 ; 4)$ бали серед дітей з ГП та 3 $(2 ; 3)$ бали у групі ДП. Середні значення були на рівні 3,0 \pm 0,74 та 2,8 $\pm 0,74$ бала відповідно. Значення Ме $(25 \% ; 75$ \%) пункту «взаємодія 3 однолітками» були однаковими - $3(2 ; 3)$ бали, а середні значення у групах ГП та ДП склали 2,7 $\pm 0,61$ та 2,8 \pm 0,59 бала. Показники Ме (25 \%; $75 \%$ ) пункту «гра з предметами» також були однаковими у групах - $3(2 ; 3)$ бали. А показники середніх значень у групах ГП та ДП становили 2,7 \pm 0,61 та 2,8 \pm 0,59 бала відповідно. Відмінностей за цими пунктами не встановлено $(\mathrm{p}>0,05)$.

Показники Ме (25 \%; 75 \%) пункту «інформація про себе» було встановлено на рівні 3 (2; 3) бали в обох групах, при середньому 2,7 $\pm 0,85$ бала у дітей з ГП та $2,9 \pm 0,97$ бала у дітей з ДП ( $>>0,05)$. Отримані бали за пункт «орієнтація в часі» зафріксовано на рівнях $3(2 ; 3)$ та $3(2 ; 3,75)$ бали у дітей груп ГП та ДП відповідно (p > 0,05). Середні значення становили 2,7 $\pm 0,97$ та 2,8 \pm $\pm 0,88$ бала. Пункт «домашні обов'язки» мав показники на рівні $1,5(1 ; 2)$ та $1(1 ; 2)$ бал у групах ГП та ДП ( $>>0,05)$. Середні значення отримано на рівні 1,5 $\pm 0,51$ та 1,3 \pm 0,71 бала відповідно.

Отримані показники при оцінці пункту «самозахист» було встановлено на рівні $2(1 ; 2)$ бали серед дітей групи ГП та $2(1 ; 3)$ бали серед дітей
Спортивна медицина і фізична реабілітація, № 1, 2018

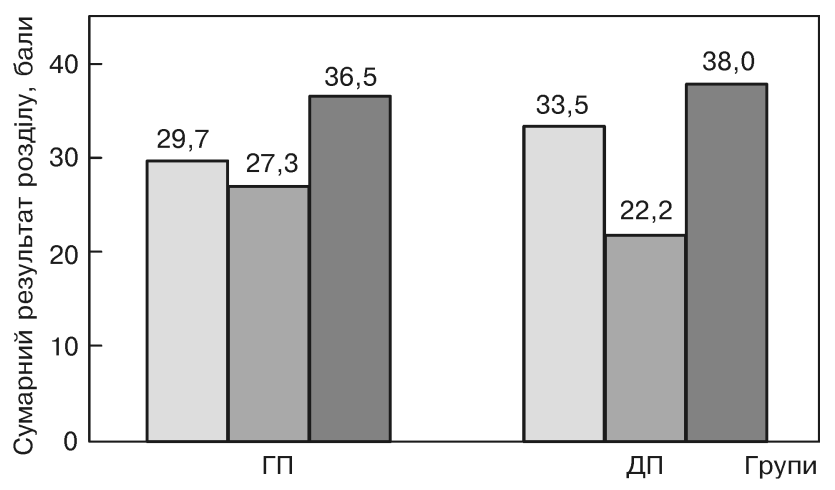

Рисунок 1 - Сумарні бали Педіатричної оцінки обмежень активності у дітей з геміплегічною (ГП) та диплегічною (ДП) формами церебрального паралічу за розділами:

$\square-$ самообслуговування; $\square-$ мобільність; $\square-$ соціальна функціональність

групи ДП ( $>$ 0,05). Середні значення відповідно 2,0 $\pm 0,89$ та 2,2 $\pm 1,03$ бали. Оцінка пункту «функції в соціумі» виявила статистичні показники Мe $(25 \% ; 75 \%)$ у групах на рівні $2(1 ; 2)$ бали при середніх значеннях у 1,7 $\pm 0,48$ та 1,8 $\pm 0,80$ бала серед груп ГП та ДП відповідно ( $>>0,05)$.

Значення Ме $(25 \% ; 75 \%)$ загальної суми розділу соціальної функціональності за PEDI становили $37(32 ; 40)$ та $39(35 ; 42)$ балів у групах 3 ГП і ДП ( $p>0,05)$.

Середні бали за розділами самообслуговування, мобільність та соціальна функціональність наведено на рисунку 1.

Отже, найнижчий бал спостерігався у розділі мобільність серед пацієнтів з ДП, а найвищий - у розділі соціальної фрункціональності також у цій групі дітей.

Серед оцінок розділу самообслуговування найнижчі бали в обох групах пацієнтів встановлено у пунктах «миття тіла та обличчя», «застібки», «взуття/шкарпетки». Ці результати поряд з індивідуальними цілями та бажаннями дітей, батьків $\epsilon$ основою для наповнення програми щодо формування навичок самообслуговування та підвищення рівня побутової і соціальної активності. Загалом низькі бали у розділі мобільність свідчать про необхідність покращення здатності до переміщення з урахуванням потреб пацієнта та впливу підтримання рівноваги під час виконання тієї чи іншої діяльності (вдягання, гра, допомога у побуті).

Висновки. У групі ГП за класифікацією GMFCS найбільша частка дітей відповідала III рівню, а у групі ДП - IV. За класифікацією MACS у групі дітей з геміплегією III рівень мала більшість дітей, що також відзначалося й у групі $з$ диплегією. 
Середні значення загальної суми розділу самообслуговування за PEDI становили 29,7 $\pm 8,09$ бала у групі дітей з ГП та 33,5 \pm 7,58 бала у групі з ДП із 73 можливих. Розмах діапазону отриманих значень був обмежений балами на рівні $17 \mathrm{i}$ 48 балів. Таким чином, групи дітей мали значно знижені показники. Отримані значення загальної суми розділу мобільності становили 27,3 \pm 9,72 бала у ГП та 22,2 \pm 8,05 бала у групі ДП із 59 можливих. Розмах діапазону отриманих значень був обмежений балами на рівні 14 і 49 балів. Тобто мобільність обстежених дітей теж була знижена. Розраховані середні значення загальної

\section{Література}

1. Алёшина А. Физическое развитие ребенка, больного детским церебральным параличом / А. Алёшина // Молодіж. наук. вісн. Східноєвроп. нац. ун-ту ім. Лесі Українки // Фіз. виховання і спорт. - 2014. - № 14. C. $97-100$.

2. Альошина А. І. До проблеми дитячого церебрального паралічу. Фізичне виховання, спорт і культура здоров'я у сучасному суспільстві: зб. наук. пр. - 2014. - № 3 (27). - С. 76-79.

3. Бардашевський Ю. В. Корекція рухової функції учнів з наслідками дитячого церебрального паралічу засобами фізичної реабілітації : автореф. дис. ...канд. наук з фріз. вих. : спец. 24.00.03. - К., 2011. - 22 с.

4. Вітомський В. В. Оцінка впливу технології фізичної реабілітації на дихальну систему дітей з функціонально єдиним шлуночком серця після гемодинамічної корекції / В. В. Вітомський // Слобожан. наук.-спорт. вісн. Х.: ХДАФК. - 2015. - № 6(50). - C. 44-47. - DOI: http://dx.doi.org/10.15391/ snsv.2015-6.007.

5. Вітомський В. Методичні основи побудови програми із фізичної реабілітації для дітей шкільного віку з функціонально єдиним шлуночком серця / В. Вітомський // Молодіж. наук. вісн. Східноєвроп. нац. ун-ту ім. Л. Українки. Сер. Фіз. виховання і спорт. - 2015. - Вип. 18. - С. 111-116.

6. Вітомський В. Показники біогеометричного профілю постави та якості життя у дітей з функціонально єдиним шлуночком серця / B. Biтомський, О. Лазарєва // Фіз. виховання, спорт і культура здоров'я у суч. суспільстві : зб. наук. пр. Луцьк : Східноєвроп. нац. ун-т ім. Лесі Українки. 2015. - № 4 (55). - C. 156-160.

7. Качмар О. О. Система класифікації функції руки в дітей із церебральним паралічем: українська версія / О. О. Качмар, В. І. Козявкін, Т. Б. Волошин, Х. О. Вітик та ін. // Журн. неврології ім. Б. М. Маньковського. - 2016. - Т. 4, № 2. - С. 31-34.

8. Мальщев С. Б. Оценка ежедневной активности, участия в жизни общества и качества жизни 63 с [ Электронный ресурс] / С. Б. Мальцев. Режим доступа: http://manuals.sdc-eu.info/library/12_t2.pdf

9. Роменська Т. Г. Особливості формування соціально-побутових навичок у дошкільників з типовим розвитком та з дитячим церебральним паралічем / Т. Г. Роменська // Наук. зап. Тернопіл. нац. пед. ун-ту iм. В. Гнатюка. Сер. Педагогіка. 2016. - № 3. - C. 175-182. - URI: http:// dspace.tnpu.edu.ua/handle/123456789/7030

10. Шевцов А. Г. Сучасні міждисциплінарні підходи до етапної комплексної реабілітації дітей із церебральним паралічем / А. Г. Шевцов, Г. М. Хворова // Наук. часопис Нац. пед. ун-ту ім. М. П. Драгоманова. Сер. 19. Корекційна педагогіка та спеціальна психологія. - 2013. - № 23. C. 281-285.

11. Шевцов А. Г. Окупаціональна терапія як міждисциплінарна сфера реабілітаційної діяльності. Науковий часопис Нац. пед. ун-ту імені М. П. Драгоманова. Сер. № 19. Корекційна педагогіка та психологія. 2007. - № 8. - 120 c. - C. 81 - 88.

12. Choi B. C. Multidisciplinarity, interdisciplinarity and transdisciplinarity in health research, services, education and policy: 1. Definitions, objectives, and evidence of effectiveness / B. C. Choi, A. W. Pak // Clin. Invest. Med. 2006. - 29(6). - P. 351-364 суми розділу соціальної функціональності за PEDI становили 36,5 \pm 4,94 бала у групі дітей з ГП та 38,0 \pm 5,33 бала у групі з ДП. Розмах діапазону отриманих значень був обмежений на рівні 26 і 46 балів, що констатувало досить низькі результати.

Отримані показники рівня активності та участі дітей з церебральним паралічем свідчать про необхідність вжиття заходів щодо їх поліпшення, основними з яких $\epsilon$ ерготерапія та фрізична терапія.

Перспективи подальших досліджень полягають у розробленні програми ерготерапії та фрізичної терапії.

\section{References}

1. Aleshina, A. (2014). Fizicheskoe razvitie rebenka, bolnogo detskim tserebralnym paralichom [Physical Development of Child, Patient with Child's Cerebral Paralysis]. Molodizhnyy naukovyy visnyk Skhidnoyevropeys'koho natsional'noho universytetu imeni Lesi Ukrayinky - Youth Scientific Bulletin of the Lesia Ukrainka Eastern European National University, 14, 97-100 [in Russian].

2. Aleshina, A.I. (2014). Do problemy dytyachoho tserebralınoho paralichu [To the Problem of Child's Cerebral Paralysis]. Fizychne vykhovannya, sport i kul'tura zdorov"ya u suchasnomu suspil'stvi - Physical education, sports and health culture in modern society, 3(27), 76-79 [in Ukrainian].

3. Bardashevskyy, Y.V. (2011). Korektsiya rukhovoyi funktsiyi uchniv z naslidkamy dytyachoho tserebral'noho paralichu zasobamy fizychnoyi reabilitatsiyi [Correction of motion functions of students with the consequences of cerebral palsy by means of physical rehabilitation]. Extended abstract of Candidate's thesis. Kyiv [in Ukrainian].

4. Vitomskiy, V.V. (2015). Ocinka vplivu tekhnologii fzichnoi reabilitacii na dikhal'nu sistemu ditej z funkcional'no iedinim shlunochkom sercia pislia gemodinamichnoi korekcii [Assessment of physical rehabilitation technology's influence on respiratory system of children with functionally one ventricular after haemo-dynamic correction]. Slobozhans'kij naukovo-sportivnij visnik - Slobozhansky scientific and sports newsletter, 6(50), 44-47. Retrieved from doi:10.15391/snsv.2015-6.007 [in Ukrainian].

5. Vitomskiy, V. (2015). Metodichni osnovi pobudovi programi iz fzichnoi reabilitacii dlia ditej shkil'nogo viku z funkcional'no iedinim shlunochkom sercia [Medical principles of building physical rehabilitation program for school age children with functionally one ventricular]. Molodizhnyy naukovyy visnyk Skhidnoyevropeys'koho natsional'noho universytetu imeni Lesi Ukrayinky - Youth Scientific Bulletin of the Lesia Ukrainka Eastern European National University, 18, 111-116 [in Ukrainian].

6. Vitomskiy, V., \& Lazarieva, O. (2015). Pokazniki biogeometrichnogo profiliu postavi ta iakosti zhittia u ditej z funkcional'no iedinim shlunochkom sercia [Indicators of posture bio-geometrical indicators and life quality of children with functionally one ventricular]. Fizychne vykhovannya, sport i kul'tura zdorov'ya u suchasnomu suspil'stvi - Physical education, sports and health culture in modern society, 4(55), 156-160 [in Ukrainian].

7. Kachmar, O.O., Koziavkin, V.I., Voloshyn, T.B., Vityk, Kh.O., \& Kalynovych, N.R. (2016). Systema klasyfikatsiyi funktsiyi ruky v ditey iz tserebral'nym paralichem: ukrayins'ka versiya [Manual Ability Classification System for children with cerebral palsy. Ukrainian version]. Zhurnal nevrolohiyi imeni B. M. Man'kovs'koho - Journal of Neurology named after B. M. Mankovsky, 4(2), 31-34 [in Ukrainian].

8. Maltsev, S.B. Otsenka ezhednevnoi aktivnosti uchastiia v zhizni obshchestva $i$ kachestva zhizni [Estimation of daily activity, participation in the life of society and quality of life]. Access mode: http://manuals.sdc-eu. info/library/12_t2.pdf [in Russian].

9. Romens'ka, T.G. (2016). Osoblyvosti formuvannya sotsial'nopobutovykh navychok u doshkil'nykiv z typovym rozvytkom ta z dytyachym tserebral'nym paralichem [The peculiarities of social and living skills formation of preschoolers with typical development and children's cerebral palsy] 
13. Fragala-Pinkham M. Introduction to the Pediatric Evaluation of Disability Inventory Computerized Adaptive Test (PEDI-CAT) for Children with Cerebral Palsy. A New Option for Measuring Function in Daily Activities, Mobility, Social / M. Fragala-Pinkham, B. Shore, J. Kramer //Cognitive and Responsibility [Електронний режим]. - 2015. - 81 р. - Режим доступу: https://www.aacpdm.org/UserFiles/file/IC33-Fragala-Pinkham.pdf

14. Glanzman A. M. Intrarater range of motion reliability in cerebral palsy: a comparison of assessment methods / A. M. Glanzman, A. E. Swenson, H. Kim // Pediatric Physical Therapy. - 2008. - T. 20. - №. 4. - C. 369-372.

15. Gunel K. M. Rehabilitation of children with cerebral palsyfrom a physiotherapist's perspective / K. M. Gunel // Acta Orthop Traumatol Turc. 2009. - 43(2). - P. 173-180. - doi:10.3944/AOTT.2009.173

16. Guyard $A$. Impact on parents of cerebral palsy in children: a literature review // A. Guyard, J. Fauconnier, A. M. Mermet, C. Cans // Arch Pediatr. 2011. - 18(2). - P. 204-214.

17. Morris C. Gross Motor Function Classification System: impact and utility / C. Morris, D. Bartlett // Developmental Medicine and Child Neurology. 2004. - Vol. 46. - P. 60-65.

18. Odding $E$. The epidemiology of cerebral palsy: incidence, impairments and risk factors / E. Odding, M. E. Roebroeck, H. J. Stam // Disabil Rehabil. 2006. - 28(4). - P. 183-91.

19. Paskaleva $R$. Features of kinesitherapy and ergotherapy for children with cerebral damage / R. Paskaleva, S. Mihaylova, K. Mollova, M. Petrova /I Trakia J. of Sci. - 2010. - T. 8, № 2. - C. 346-348.

20. Rosenbaum P. A report: the definition and classification of cerebral palsy April 2006 / P. Rosenbaum, N. Paneth, A. Leviton et al. // Dev Med Child Neurol Suppl. - 2007. -109. - P. 8-14.

21. Shepherd R. B. Cerebral palsy. In: Physiotherapy in paediatrics. 3rd ed. / R. B. Shepherd. - Oxford: Butterworth-Heinemann. - 1995. - P. 110-144.

22. Stavsky M. Palsy-Trends in Epidemiology and Recent Development in Prenatal Mechanisms of Disease, Treatment, and Prevention / M. Stavsky, O. Mor, S. A. Mastrolia et al. // Front Pediatr. - 2017. - Vol. 5, Article 21. 10p. - doi: 10.3389/fped.2017.00021.

23. Steultjens E.M.J. Ende C.H.M. Occupational therapy for children with cerebral palsy / E.M.J. Steultjens, J. Dekker, L. M. Bouter et al. // Cochrane Database of Systematic Reviews. - 2003(4). - 7p. - https://postprint.nivel.nl/ PPpp1798.pdf

24. Trabacca A. Multidisciplinary rehabilitation for patients with cerebral palsy: improving long-term care / A. Trabacca, T. Vespino, A. Di Liddo, L. Russo // J. of Multidisciplinary Healthcare. - 2016. - Vol. 9. - P. 455-462.

25. Vitomskiy V. V. Dynamic of bio-geometric profile indicators of children's with functionally one ventricle posture at stage of physical rehabilitation / V. V. Vitomskiy, O. B. Lazarieva, E. V. Imas et al. // Pedagogics, psychology, medical-biological problems of physical training and sports. - 2017. - 21(3). P. 146-151. - doi:10.15561/18189172.2017.0308
Naukovi zapysky Ternopil's'koho natsional'noho pedahohichnoho universytetu imeni V. Hnatyuka (Ser. Pedahohika) - Scientific notes of the Ternopil National Pedagogical University named after V. Hnatyuk (Ser. Pedagogy), 3, 175-182 [in Ukrainian].

10. Shevcov, A.G., \& Hvorova, G.M. (2013). Suchasni mizhdystsyplinarni pidkhody do etapnoyi kompleksnoyi reabilitatsiyi ditey iz tserebral'nym paralichem [Modern interdisciplinary approaches to the stage complex rehabilitation of children with cerebral palsy]. Naukovyy chasopys natsional'noho pedahohichnoho universytetu imeni M.P. Drahomanova (Ser. 19 «Korektsiyna pedahohika ta spetsial'na psykholohiya») - Journal of the National Pedagogical University named after M.P. Drahomanov (Ser. 19 "Correctional Pedagogy and Special Psychology»), 23, 281-285 [in Ukrainian]

11. Shevtsov, A.G. (2007). Okupatsional'na terapiya yak mizhdystsyplinarna sfera reabilitatsiynoyi diyal'nosti [Occupational therapy as an interdisciplinary sphere of rehabilitation activity]. Naukovyy chasopys natsional'noho pedahohichnoho universytetu imeni M.P. Drahomanova (Ser. 19 «Korektsiyna pedahohika ta spetsial'na psykholohiya») - Journal of the National Pedagogical University named after M.P. Drahomanov (Ser. 19 «Correctional Pedagogy and Special Psychology»), Vol. 8, 81-88 [in Ukrainian].

12. Choi, B.C. \& Pak, A.W. (2006). Multidisciplinarity, interdisciplinarity and transdisciplinarity in health research, services, education and policy: 1 Definitions, objectives, and evidence of effectiveness. Clin. Invest. Med., Vol. 29, Iss. 6, 351-364

13. Fragala-Pinkham, M., Shore, B., \& Kramer, J. (2015). Introduction to the Pediatric Evaluation of Disability Inventory Computerized Adaptive Test (PEDI-CAT) for Children with Cerebral Palsy. A New Option for Measuring Function in Daily Activities, Mobility, Social/Cognitive and Responsibility. Access mode:[https://www.aacpdm.org/UserFiles/file/IC33-Fragala-Pinkham.pdf]

14. Glanzman, A.M., Swenson, A.E., \& Kim, H. (2008). Intrarater range of motion reliability in cerebral palsy: a comparison of assessment methods. Pediatric Physical Therapy, Vol. 20, Iss. 4, 369-372.

15. Gunel, K.M. (2009). Rehabilitation of children with cerebral palsy from a physiotherapist's perspective. Acta Orthop. Traumatol. Turc., Vol. 43, Iss. 2, 173-180. Retrieved from doi:10.3944 IAOTT.2009.173.

16. Guyard, A., Fauconnier, J., Mermet, M.A., \& Cans, C. (2011). Impact on parents of cerebral palsy in children: a literature review. Arch. Pediatr. Vol. 18, Iss. 2, 204-214.

17. Morris, C., \& Bartlett, D. (2004). Gross Motor Function Classification System: impact and utility. Developmental Medicine and Child Neurology, Vol. 46, 60-65.

18. Odding, E., Roebroeck, M.E., \& Stam, H.J. (2006). The epidemiology of cerebral palsy: incidence, impairments and risk factors. Disabil Rehabil., Vol. 28, Iss. 4, 183-191.

19. Paskaleva, R., Mihaylova, S., Mollova, \& K., Petrova, M. (2010). Features of kinesitherapy and ergotherapy for children with cerebral damage. Trakia Journal of Sciences, Vol. 8, Iss. 2, 346-348.

20. Rosenbaum, P., Paneth, N., Leviton, A., Goldstein, M., Bax, M., Damiano, D., Dan, B., \& Jacobsson, B. (2007). A report: the definition and classification of cerebral palsy April 2006. Dev. Med. Child. Neurol. Suppl., Vol. 109, 8-14.

21. Shepherd, R.B. (1995). Cerebral palsy. In: Physiotherapy in paediatrics. Oxford: Butterworth-Heinemann, 110-144.

22. Stavsky, M., Mor, O., Mastrolia, S.A., Greenbaum, S., Than, N.G., \& Erez, O. (2017). Cerebral Palsy-Trends in Epidemiology and Recent Development in Prenatal Mechanisms of Disease, Treatment, and Prevention. Front Pediatr., Vol. 5, Article 21. Retrieved from doi: 10.3389/fped.2017.00021.

23. Steultjens, E.M.J., Dekker, J., Bouter, L.M., Nes, J.C.M., Lambregts, B.L.M., \& Ende, C.H.M. (2003). Occupational therapy for children with cerebral palsy. Cochrane Database of Systematic Reviews, Vol. 4. Access mode: [https://postprint.nivel.nl/PPpp1798.pdf].

24. Trabacca, A., Vespino, T., Di Liddo, A., \& Russo, L. (2016). Multidisciplinary rehabilitation for patients with cerebral palsy: improving long-term care. J. of Multidisciplinary Healthcare, Vol. 9, 455-462.

25. Vitomskiy, V.V., Lazarieva, O.B., Imas, E.V., Zhovnir, V.A., \& Emets, I.N. (2017). Dynamic of bio-geometric profile indicators of children's with functionally one ventricle posture at stage of physical rehabilitation. Pedagogics, psychology, medical-biological problems of physical training and sports, 21(3), 146-151. Retrieved from doi: 10.15561/18189172.2017.0308.

Надійшла 25.01.2018 